\title{
Results of acromioclavicular joint reconstruction using a novel minimally invasive technique
}

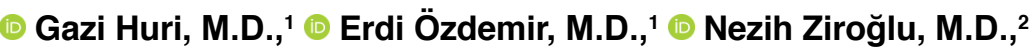 \\ (D) John Costouros, M.D., ${ }^{3}$ (1) Edward McFarland, M.D. ${ }^{4}$
}

\author{
${ }^{1}$ Departmant of Orthopaedics and Traumatology, Hacettepe University Faculty of Medicine, Ankara-Turkey \\ 2Departmant of Orthopaedics and Traumatology, Bakirköy Dr. Sadi Konuk Training and Research Hospital, İstanbul-Turkey \\ ${ }^{3}$ Departmant of Orthopaedics and Traumatology, Stanford University, CA-USA \\ ${ }^{4}$ Departmant of Orthopaedics and Traumatology, Shoulder Division Johns Hopkins University, MD-USA
}

\begin{abstract}
BACKGROUND: AC joint injury is a common disorder with a reported incidence of three to four cases per 100.000 . A multitude of surgical techniques has been described for the treatment of the $A C$ joint injuries with no clear consensus regarding the optimal treatment. We hypothesized that we would obtain favorable clinical outcomes using a novel minimally-invasive polymer cerclage wire system compared to other reported techniques in the literature.
\end{abstract}

METHODS: All adult patients treated with subacute AC separations in our department between the dates of 2014-2017 were retrospectively reviewed clinically and radiographically. Clinical outcomes scores that were obtained preoperatively and postoperatively included ASES score, constant score and the UCLA shoulder rating scale.

RESULTS: Five patients with Type $5 \mathrm{AC}$ separations were included in this study who underwent surgical treatment by the same orthopedic surgeon (G.H.) using the same minimally-invasive technique. The mean follow-up period was 22.4 months (range 18 to 29). Mean preoperative coracoclavicular (CC) distance was $19.7 \mathrm{~mm}$ (range 16.4 to $24.5 \mathrm{~mm}$ ) on the surgical side and $9.48 \mathrm{~mm}$ on the contralateral side. Mean early postoperative CC distance was $7.1 \mathrm{~mm}$ (range 4.5 to $11.2 \mathrm{~mm}$ ). At the latest follow-up, the mean CC distance was $13.8 \mathrm{~mm}$ (range 7.3 to $21.2 \mathrm{~mm}$ ). Mean preoperative Constant score was 48 , the UCLA shoulder rating score was 14.8, and the ASES shoulder score was 49.26. Mean follow up Constant score was 91.6, UCLA shoulder rating score was 33.8 and ASES shoulder score was 93.75. No neurovascular complication was observed after procedure. There were no cases of clinical or radiographic failure or loss of fixation. No AC joint arthritis was observed at the latest follow-up.

CONCLUSION: We present a novel minimally-invasive polymer cerclage wire technique which provides comparable results as other reported arthroscopic and open techniques for Type 5 AC joint separations.

Keywords: AC joint; acromioclavicular; dislocation; injury; shoulder.

\section{INTRODUCTION}

Acromioclavicular (AC) joint injury is a common disorder and seen in approximately three to four cases per 100.000. ${ }^{[1]} \mathrm{AC}$ joint injury comprises $12 \%$ of injuries about the shoulder gir$\mathrm{dle}^{[2]}$ and the incidence is rising due to increased participation in high-impact sports injuries and a reported increase in motorcycle accidents. ${ }^{[1,3]}$
The most common classification system continues to be that described by Rockwood and is based on the degree of displacement of the distal clavicle relative to the acromion. Rockwood described six types of AC separations: Type I injury is a mild sprain of AC ligament; Type 2 is a rupture of the AC ligament and sprained CC ligaments; Type 3 is a superior dislocation of the distal clavicle with ruptured $A C$ and $C C$ ligaments and joint capsule; Type 4 injury is a posterior dis-

Cite this article as: Huri G, Özdemir E, Ziroğlu N, Costouros J, McFarland E. Results of acromioclavicular joint reconstruction using a novel minimally invasive technique. Ulus Travma Acil Cerrahi Derg 2020;26:260-264.

Address for correspondence: Gazi Huri, M.D.

Hacettepe Üniversitesi Tıp Fakültesi, Ortopedi ve Travmatoloji Anabilim Dalı, Ankara, Turkey

Tel: +90 312 - 3051080 E-mail: gazihuri@yahoo.com

Ulus Travma Acil Cerrahi Derg 2020;26(2):260-264 DOI: 10.14744/tjtes.2019.36897 Submitted: 21.05.2019 Accepted: 14.06.2019 Online: 21.02 .2020

Copyright 2020 Turkish Association of Trauma and Emergency Surgery 
location of the distal clavicle; Type 5 injury is a Type 3 injury with $300 \%$ superior dislocation of the distal clavicle; Type 6 injury is an inferior dislocation the distal clavicle. ${ }^{[4]}$ Treatment of $A C$ joint injuries is considered according the degree of injury. Non-operative treatment has traditionally been recommended for Rockwood Type 1-2 injuries, however, the accepted treatment of choice for Rockwood 3-6 continues to be controversial. ${ }^{[5]}$

Several numbers of techniques have been described for the surgical treatment of $A C$ joint injuries but no clinical superiority of one technique over another has surfaced. ${ }^{[6]}$ With this study we describe a minimally invasive coracoclavicular (CC) ligament reconstruction technique for the treatment of Type 5 AC joint separations using Ortholox ${ }^{\odot}$ (Ankara, Turkey), an Ultra-high molecular polyethylene weight polietilen-based cerclage system, which is commonly used for spine surgery during the deportation process. We hypothesized that we will obtain favorable clinical outcomes compared to other reported techniques in the literature.

\section{MATERIALS AND METHODS}

This retrospective case series was designed to show the results of $A C$ joint reconstruction using a OrtholoxGH ${ }^{\circledR}$ Cerclage Band System technique. This study was approved by the local ethics committee (number: GO 18/589). Eleven Type 5 AC joint injuries underwent surgical treatment our clinic between 2014-2017. Patients who underwent with other surgical techniques for Grade 5 AC joint separations were excluded from this study. Five patients were included this study who were operated on by the same orthopedic surgeon (G.H.) using the same technique. All patients were male. Mean age was 40 (range 26 to 67 ). Three of the patients injured their shoulder during a traffic accident, one patient during a water sport activity, and one after a fall onto his shoulder (Table I). All injuries were subacute cases. All patients were recorded as Rockwood Type 5 AC joint injuries using standardized plain radiographs in the AP and axillary lateral projections in the sitting position and without traction. The dominant side was affected in three out of five patients. Radiologic evaluation was performed preoperative and serial postoperative X-rays (Fig. Ia, b). CC distance was measured on X-rays and defined as the vertical distance between the superior surface of coracoid and the inferior surface of the clavicle. Functional outcome scores were analyzed with ASES shoulder score, constant shoulder score and UCLA shoulder rating scale on their follow-up visits.

\section{Surgical Technique}

Following the induction of general anesthesia, the patient was placed in the modified beach chair position, taking care to pad all bony prominences and appropriately position the neck and contralateral extremity. The shoulders were examined under anesthesia and showed no evidence of glenohumeral joint instability with well-preserved passive range of motion in all planes, but with obvious asymmetry and deformity at the AC joint (Fig. 2a). Intraoperative fluoroscopy was used to confirm the type of $A C$ joint separation.

The surgical procedure was performed with a special instrumentation set designed for his particular surgical technique (Fig. 2b). Two small incisions were made over the clavicle and coracoid process in a parallel fashion (Fig. 2c). The superior incision was made and carried sharply down to the underlying deltotrapezial fascia, which was opened in line with the clavicle. The inferior incision was performed meticulously to expose the coracoid.

Following blunt dissection of the soft tissues, the distal clavicle and coracoid process were clearly visualized. Through the inferior incision a flexible suture manipulator (Fig. 2b) was used to pass the polymer cerclage cable around the base of the coracoid. Once passed, a subcutaneous tunnel was created between the superior and inferior incisions. The free ends of the cerclage cable were carried to superior incision
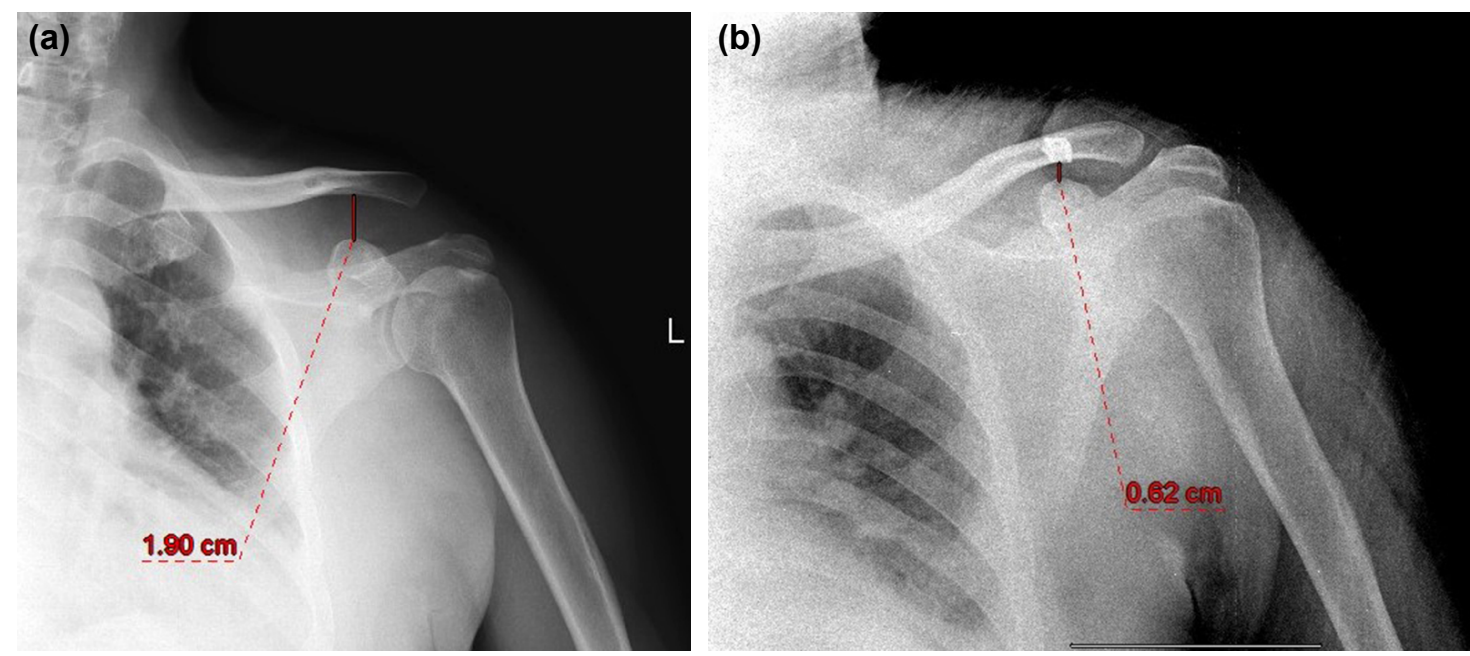

Figure 1. (a) Preoperative X-ray, Rockwood type 5 AC injury. (b) Postoperative X-ray, demonstrating reduced AC joint. 

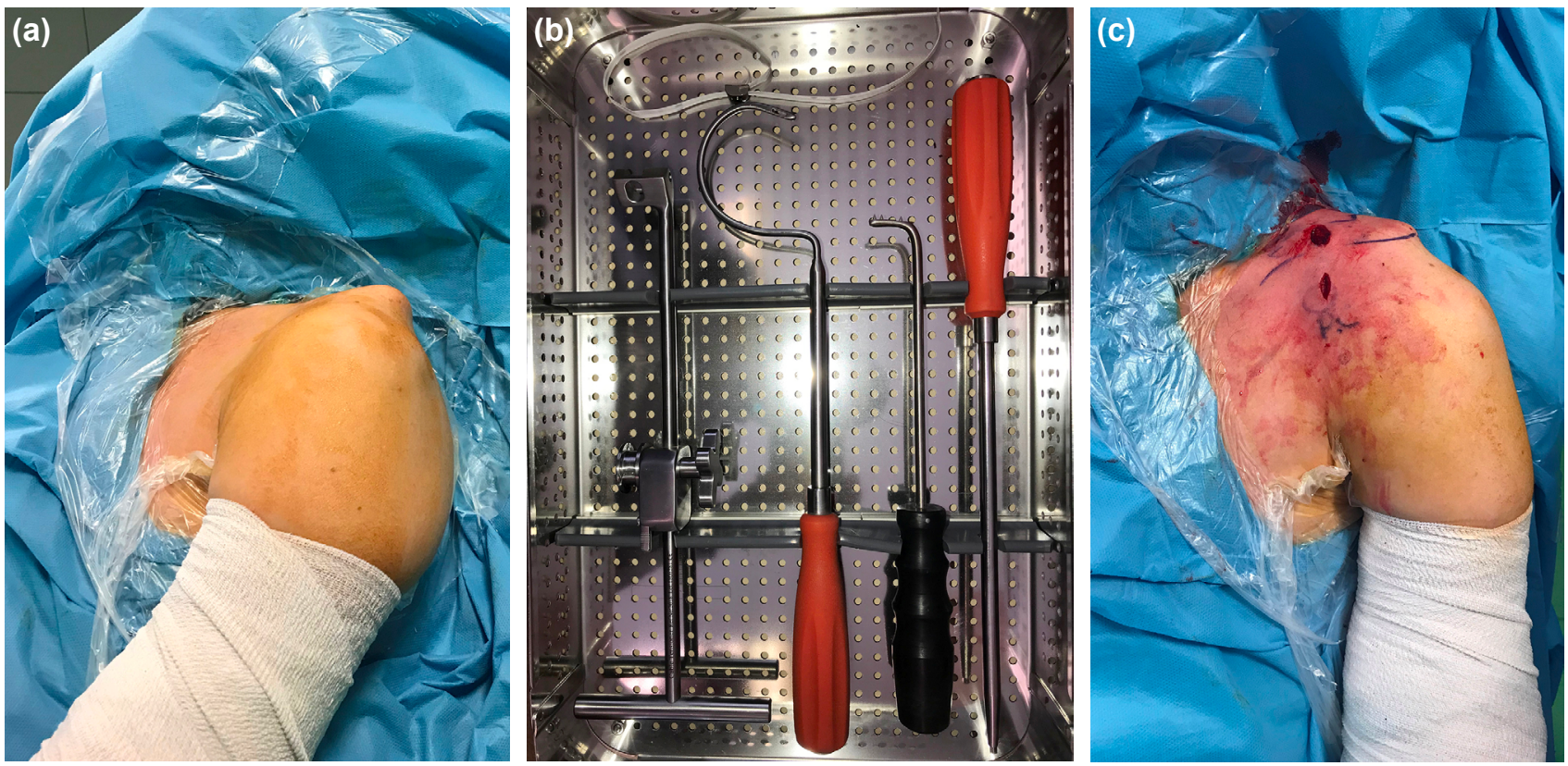

Figure 1. (a) Clinical deformity of the patient. (b) Polimer cerclage wire system. (c) 2 mini incisions of the minimally invasive technique.

through the tunnel. Next, the cable, already looped under the coracoid, was looped around the clavicle and tensioned using a tension device. After the AC joint reduction was confirmed with fluoroscopic guidance, the cable was locked with a set screw.

\section{RESULTS}

Mean follow-up period was 22.4 months (range 18 to 29). Mean preoperative CC distances were $19.7 \mathrm{~mm}$ (range 16.4 to $24.5 \mathrm{~mm}$ ) on the operated side and $9.48 \mathrm{~mm}$ on the contralateral side (Table 2). Mean early postoperative CC distance was $7.1 \mathrm{~mm}$ (range 4.5 to $11.2 \mathrm{~mm}$ ). Mean latest followup CC distance was $13.8 \mathrm{~mm}$ (range 7.3 to $21.2 \mathrm{~mm}$ ). Mean preoperative Constant score was 48, UCLA shoulder rating score was 14.8 and ASES shoulder score was 49.26. Mean follow up Constant score was 91.6, UCLA shoulder rating score was 33.8 and ASES shoulder score was 93.75 (Table 3). No neurovascular complications or implant failures occurred in any of the patients. No AC joint arthritis was observed.

Table I. Patient demographics

\begin{tabular}{lc}
\hline Patient demographics & \\
\hline Sex & \\
$\quad$ Male & 5 \\
$\quad$ Female & 0 \\
Mean age & $40(26-67)$ \\
Injury side & \\
$\quad$ Dominant hand & 3 \\
$\quad$ Non-dominant hand & 2 \\
\hline
\end{tabular}

\section{DISCUSSION}

In the present study, we describe a novel, minimally-invasive technique for the reconstruction of the coracoclavicular ligaments in grade $5 \mathrm{AC}$ joint injuries using a polymer cerclage. Although several surgical techniques have been described for

Table 2. Radiographic evaluation

Coracoclavicular distance

Preoperative

$\begin{array}{lc}\text { Effected side } & 19.7 \mathrm{~mm}(16.4-24.5) \\ \text { Contralateral side } & 9.48 \mathrm{~mm}(6.4-14.9) \\ \text { Early postoperative } & 7.1 \mathrm{~mm}(4.5-11.2) \\ \text { Follow-up visit } & 13.8 \mathrm{~mm}(7.3-21.2)\end{array}$

Table 3. Patient reported functional outcome measures

\begin{tabular}{lc}
\hline Outcome measure & Results \\
\hline $\begin{array}{l}\text { Constant score } \\
\quad \text { Preoperative }\end{array}$ \\
$\quad$ Latest follow-up visit & $48(43-52)$ \\
UCLA shoulder rating scale & $91.6(90-94)$ \\
$\quad$ Preoperative & \\
$\quad$ Latest follow-up visit & $14.8(8-18)$ \\
ASES score & $33.8(33-35)$ \\
$\quad$ Preoperative & \\
Latest follow-up visit & $49.26(36.6-54.9)$ \\
\hline
\end{tabular}


the treatment Type $5 \mathrm{AC}$ joint injuries, none of the defined techniques have shown clinical superiority. ${ }^{[3]}$ Historically, surgical management strategies have varied widely from open reduction, direct repair of the $A C$ capsule, and rigid internal fixation to minimally invasive techniques and arthroscopic procedures for reconstruction of the AC joint. ${ }^{[3]}$ Most reported complications and residual pain are related to implant failure or progression of arthritis of the AC joint. ${ }^{[3]}$ In this paper, we aimed to examine the results of our minimally invasive technique parallel to developing treatment strategies.

Acute AC separation treatment strategies can be classified as rigid and non-rigid fixations. In terms of rigid fixation, screws, K-wires and hook plates can be used. These rigid fixation devices aim to maintain the $A C$ joint in a reduced position while biological healing can occur. ${ }^{[7]}$ The primary problems observed in screw and K-wire fixation are migration, osteolysis, loss of reduction and implant breakage. They also require an additional surgery for implant removal. ${ }^{[5]}$ Another rigid fixation device is the hook plate which provides stronger stability. However, the hook plate which is inserted under acromion causes subacromial impingement and rotator cuff lesions. Also, it may cause shoulder pain in some cases. ${ }^{[8]}$ Because of these inherent disadvantages, non-rigid fixation instruments are preferred for the AC joint separations today. These non-rigid treatment options include the endobutton sutures and CC ligament reconstructions. Endobutton technique carries the advantage of less soft tissue disruption during implantation and providing motion between scapula and clavicle. It has some disadvantages like button breakage, migration and clavicle fracture. ${ }^{[9,10]} \mathrm{CC}$ ligament reconstruction also requires a graft for additional strength of fixation. This method carries the additional burden of donor site morbidity with similar functional outcomes. ${ }^{[1]}$ Our fixation method with polymer cerclage cable is a non-rigid fixation and does not require additional augmentation with graft.

Regarding the fixation materials, such as wires, screws and hook plates for rigid coracoclavicular fixation, they are associated with a significant risk of migration, loosening and breakage. Other important complications of the hook plate include acromial osteolysis, dislocation of the hook and impingement due to plate. While comparing Polymer Cerclage Cable System (Ortholox) to rigid fixation materials, we can see same advantages of non-rigid group, such as reduced risk of migration and breakage. ${ }^{[5]}$ According to the literature, non-rigid coracoclavicular fixation with synthetic materials can achieve similar outcomes to fixation with a hook plate, thus eliminate the necessity of secondary surgery to remove the plate. With similar thought ortholox system could be preferred to avoid hook plate specific complications like osteolysis, dislocation and impingement. Compared to other non-rigid fixations, in endobotton technique drill holes are used for fixation of sutures. This carries the risk of clavicle fracture. In our technique fixation is obtained without of the need for bone tunnels in the clavicle. ${ }^{[9]}$ In CC ligament reconstruction technique, as fixation material semitendinosus graft is used. We do not have and donor site morbidity compared to that reconstruction technique. ${ }^{\left[{ }^{\prime \prime}\right]}$

The strengths of this technique include that it is minimally invasive technique and only two small incisions are required. This Polymer Cerclage Cable System (Ortholox) technique also has the advantage of allowing for adjustable tension and a modifiable stitch placement. Functional outcomes (ASES, Constant, UCLA shoulder scores) are comparable to other reported techniques in the orthopaedic literature using endobutton fixation as well as the hook plate. ${ }^{[12,13]}$

Some of the disadvantages of this technique include the potential for cerclage loosening with cyclical loading over time. Two patients in this series had cerclage loosening at their latest follow-up visit that did not affect functional outcomes. We did not observe clinical failure despite radiographic evidence of loss of fixation. Even one of our patients working as a heavy worker could perform his work without complaints. All patients successfully returned to their previous level of work without any problems.

Our study had several limitations. One of them is we did not have a control group. We could only compare our results with the reported literature. Secondly, our patient population was small. Therefore, our results may not be generalized to all types of $A C$ separations. Additional studies are required for determining functional outcomes and complication rates. In conclusion, we report a novel, minimally-invasive polymer cerclage technique that appears to be comparable to other reported arthroscopic and open techniques for the treatment of Rockwood Type 5 AC separations. Further analysis of this technique in the treatment of other high-grade $A C$ separations in a larger cohort of patients with longer clinical and radiographic follow-up is warranted.

Ethics Committee Approval: Approved by the local ethics committee.

Peer-review: Internally peer-reviewed.

Authorship Contributions: Concept: G.H., J.C., E.M.; Design: G.H., E.Ö., J.C.; Supervision: G.H., E.M.; Materials: G.H., E.Ö., N.Z.; Data: G.H., E.Ö., N.Z., J.C., E.M.; Analysis: G.H., E.Ö., N.Z., J.C., E.M.; Literature search: G.H., E.Ö., N.Z., J.C., E.M.; Writing: G.H., E.Ö., N.Z., J.C., E.M.; Critical revision: G.H., J.C., E.M.

\section{Conflict of Interest: None declared.}

Financial Disclosure: The autors declared that this study has received no financial support.

\section{REFERENCES}

1. Babhulkar A, Pawaskar A. Acromioclavicular joint dislocations. Curr Rev Musculoskelet Med 2014;7:33-9. [CrossRef]

2. Emery R. Acromioclavicular and sternoclavicular joints. In: Copeland S, 
editors. Shoulder surgery. London: WB Saunders; 1997.

3. Li X, Ma R, Bedi A, Dines DM, Altchek DW, Dines JS. Management of acromioclavicular joint injuries. J Bone Joint Surg Am 2014;96:73-84.

4. Rockwood CA Jr. Injuries to the acromioclavicular joint. In: In: Rockwood CA Jr, Green DP, editors. Fractures in adults, vol 1, 2nd ed. Philadelphia: JB Lippincott; 1984. p. 860-910.

5. Modi CS, Beazley J, Zywiel MG, Lawrence TM, Veillette CJ. Controversies relating to the management of acromioclavicular joint dislocations. Bone Joint J 2013;95-B:1595-1602. [CrossRef]

6. Fraser-Moodie JA, Shortt NL, Robinson CM. Injuries to the acromioclavicular joint. J Bone Joint Surg Br 2008;90:697-707. [CrossRef]

7. van Bergen CJA, van Bemmel AF, Alta TDW, van Noort A. New insights in the treatment of acromioclavicular separation. World J Orthop 2017;8:861-73. [CrossRef]

8. Yoon JP, Lee YS, Song GS, Oh JH. Morphological analysis of acromion and hook plate for the fixation of acromioclavicular joint dislocation. Knee Surg Sports Traumatol Arthrosc 2017;25:980-6. [CrossRef]

9. Martetschläger F, Horan MP, Warth RJ, Millett PJ. Complications after anatomic fixation and reconstruction of the coracoclavicular ligaments. Am J Sports Med 2013;41:2896-2903. [CrossRef]

10. Clavert P, Meyer A, Boyer P, Gastaud O, Barth J, Duparc F; SFA. Complication rates and types of failure after arthroscopic acute acromioclavicular dislocation fixation. Prospective multicenter study of 116 cases. Orthop Traumatol Surg Res 2015;101:S313-6. [CrossRef]

11. Mazzocca AD, Santangelo SA, Johnson ST, Rios CG, Dumonski ML, Arciero RA. A biomechanical evaluation of an anatomical coracoclavicular ligament reconstruction. Am J Sports Med 2006;34:236-46. [CrossRef]

12. Xue C, Song LJ, Zhang H, Tang GL, Li X, Fang JH. Truly anatomic coracoclavicular ligament reconstruction with 2 Endobutton devices for acute Rockwood type V acromioclavicular joint dislocations. J Shoulder Elbow Surg 2018;27:e196-202. [CrossRef]

13. Arirachakaran A, Boonard M, Piyapittayanun P, Kanchanatawan W, Chaijenkij K, Prommahachai A, et al. Post-operative outcomes and complications of suspensory loop fixation device versus hook plate in acute unstable acromioclavicular joint dislocation: a systematic review and meta-analysis. J Orthop Traumatol 2017;18:293-304. [CrossRef]

\title{
ORİJINAL ÇALIŞMA - ÖZET
}

\section{Minimal invaziv teknik ile akromioklaviküler eklem rekonstrüksiyonunun sonuçları \\ Dr. Gazi Huri, ${ }^{1}$ Dr. Erdi Özdemir, ${ }^{1}$ Dr. Nezih Ziroğlu, ${ }^{2}$ Dr. John Costouros, ${ }^{3}$ Dr. Edward McFarland ${ }^{4}$}

\author{
${ }^{1}$ Hacettepe Üniversitesi Tıp Fakültesi, Ortopedi ve Travmatoloji Anabilim Dalı, Ankara \\ ${ }^{2}$ Bakırköy Dr. Sadi Konuk Eğitim ve Araştırma Hastanesi, Ortopedi ve Travmatoloji Kliniği, İstanbul, Türkiye \\ ${ }^{3}$ Stanford Üniversitesi, Ortopedi ve Travmatoloji Departmanı, USA \\ ${ }^{4}$ Johns Hopkins Üniversitesi, Ortopedi ve Travmatoloji Departmanı, Omuz Bölümü, USA
}

AMAÇ: Akromiyoklaviküler (AC) eklem hasarı, 100.000'inde 3 ile 4 sıklığında görülen bir yaralanmadır. AC eklem yaralanmalarının tedavisi için optimal tedavi konusunda net bir fikir birliği olmadığından çok sayıda cerrahi teknik tanımlanmıştı. Çalışmamızda literatürde bildirilen diğer tekniklerle karşılaştırıldığında, minimal-invaziv polimer serklaj tel sistemi ile olumlu klinik sonuçlar elde edeceğimizi hipotez edilmiştir.

GEREÇ VE YÖNTEM: Bölümümüzde 20I4-2017 tarihleri arasında subakut AC yaralanması olan tüm yetişkin hastalar geriye dönük olarak taranarak klinik ve radyografik olarak incelendi. Ameliyat öncesi ve sonrası klinik sonuçlar ASES skoru, Constant skoru ve UCLA omuz skoru ölçeği ile değerlendirildi.

BULGULAR: Çalışmaya aynı minimal-invaziv tekniği kullanarak aynı cerrah tarafından cerrahi tedavi uygulanmış tip 5 AC yaralanması olan beş hasta dahil edildi. Ortalama takip süresi 22.4 aydı (I8-29). Ameliyat öncesi ortalama korakoklavikular (CC) uzaklığı cerrahi tarafta $19.7 \mathrm{~mm}$ (I6.4-24.5 $\mathrm{mm}$ ), kontralateral tarafta $9.48 \mathrm{~mm}$ idi. Ameliyat sonrası erken dönemde ortalama CC mesafesi $7.1 \mathrm{~mm}(4.5-11.2 \mathrm{~mm})$ idi. Son takipte, ortalama CC mesafesi $13.8 \mathrm{~mm}$ (7.3-21.2 mm) idi. Ameliyat öncesi ortalama Constant skoru 48, UCLA omuz skoru 14.8, ASES omuz skoru 49.26 idi. Hastaların son takiplerinde ortalama Constant skoru 91.6, UCLA omuz skoru 33.8, ASES omuz skoru 93.75 idi. Cerrahi sonrası nörovasküler komplikasyon görülmedi. Klinik veya radyografik implant yetersizliği veya fiksasyon kaybı görülmedi. Son takipte hiçbir hastada AC eklem artriti görülmedi. TARTIŞMA: Tip 5 AC eklem yaralanmaları için bildirilen diğer artroskopik ve açık teknikler ile karşılaştırılabilir sonuçlar sağlayan yeni bir minimalinvaziv polimer serklaj tel tekniği tanımlanmıştır.

Anahtar sözcükler: Akromiklaviküler; akromiklaviküler eklemi; dislokasyon; omuz; yaralanma.

Ulus Travma Acil Cerrahi Derg 2020;26(2):260-264 doi: 10.14744/tjtes.2019.36897 